\title{
The Budget Planning Determinant Factors at State Primary Schools in Yogyakarta Province
}

\author{
Siti Maisaroh \\ Correspondence author, Yogyakarta State University, Indonesia, \\ maisaroh.siti@gmail.com \& maisarohmay65@gmail.com
}

\section{Slamet PH}

Yogyakarta State University, Indonesia, slametph@uny.ac.id

\section{Samsul Hadi}

Yogyakarta State University, Indonesia, samsul_hd@uny.ac.id

The purpose of this study is to describe the factors that influence budget planning at the State Primary School. This study uses quantitative research methods. The population in this study was the State Primary School in Yogyakarta Province in the amount of 1478 schools, with a sample of 284 schools. The sampling technique used is cluster random sampling. The collection technique uses a questionnaire. Data analysis technique uses Structural Equation Model (SEM) analysis with the help of Lisrel 8.80 Software. The results showed that; (1) there is a significant effect on the variable of school objective, school management, School Work Planning (SWP) and Operational Work Planning (OWP) on budget planning variable, with respectively $0.24,0.16,0.18$ and 0.37 : (2) There is no influence of work involvement variable on budget planning variable; (3) there is a significant effect of school objective variable, school management, and work involvement on OWP, respectively $0.28,0.32$ and 0.22 ; (4) there is a significant effect of school objective variable, school management, and work involvement on OWP of 0.29 , 0.24 and 0.24 . The measurement model developed through eleven hypotheses is fit with the data obtained in the field, because it meets the criteria of Goodness of Fit.

Keywords: determinant factors, budget planning, primary school, schools, budget

\section{INTRODUCTION}

Basic education has two functions, namely to develop the ability of students and provide a strong foundation for education at the junior high school level and the next level. Furthermore, substantially the objectives of Elementary School (ES) education must be guided by the goals of national education. To achieve the stated goals, supporting 
resources are needed to implement them. One of them is funding which is a very important part in the management of education. This source of funding is crucial in managing education. Funds or budgets are very crucial studies in the management of education.

Government Regulation No 17 of 2010 articles 50 and 51 states that education units have an obligation to formulate and establish education policies in accordance with their authority. One of the education policies that become the school's obligation is to prepare SWP and prepare annual budgets and expenditures. The government hopes that with SWP, it will be easier to monitor and evaluate school development. The SWP can be used as a working guideline and as a reference to determine the educational resources needed in school development. The SWP prepared by the school is supported by the Regional Autonomy Policy within the scope of formal education with the concept of School-Based Management (SBM). The SBM makes education in schools better in terms of management, financing, development, and supervision. The schools will become more independent, have greater authority and responsibility in managing their schools. Schools will also have flexibility in developing school programs according to the needs and abilities of school resources.

To achieve this goal, schools need to make SWP well. The SWP is a plan for school programs that will be used to achieve educational goals. The preparation of the SWP is tailored to the uniqueness, conditions of regional potential, social culture of the community and the needs of students. The SWP can be used by school principals in taking policies and can be used as guidelines in the implementation of teaching and learning programs. The purpose of SWP is that schools can find out what must be done to achieve the goals of developing schools. The SWP also ensures that all programs and activities are conducted to develop schools that are tailored to the expectations of stakeholders and school conditions. SWP is translated more operationally into OWP. The OWP is made in more detail and has a short term of one year. If the SWP is made at the beginning of the year for the next four years, then OWP is made at the beginning of the first, second, third and fourth years. This is in accordance with PP No. 19 of 2005 concerning National Education Standards in article 53 paragraph 1, which states that "every education unit is managed on the basis of an annual work plan which is a detailed description of the medium-term work plan of the education unit for a period of four years".

Well-planned planning will increase the effectiveness and efficiency of an education program. Planning will help educational institutions achieve maximum results even with limited resources. The planning process is the determination of the steps that will be taken into account to achieve school goals. Therefore, school objectives are determined jointly by the principal, teacher and school committee for the benefit of student learning. Data about planning will be used as a consideration in achieving goals that include school needs and school conditions at that time.

The success of school budgeting is influenced by the involvement of all parties, namely from the principal, teachers, students, parents, and the community. The budget planning process for school expenditure has involved principals, teachers, and school committees. 
The involvement of school principals and teachers is good, but the involvement of the school committee is still not good. The school committee signed the school budget approval, but the school committee was not involved in the budget planning process. The budget preparation team has been formed and is involved in the preparation of the school budget, but schools do not understand the ideal budget estimate. Many school programs are not implemented and the school is not committed to the budget that is prepared. Reports that have been made are less accountable because the administration is not orderly yet. Transparency of budget management is also lacking because school budgets are not socialized to people in schools.

SWP and OWP prepared by schools have not involved all school stakeholders. SWP and OWP prepared by schools have not been based on School Self Evaluation. The OWP that have been made based on the SWP implemented are often not in accordance with the implementation. The budget planning carried out in schools has not yet been guided by school needs, school objectives, selection of program alternatives and more effective cost selection. Elementary Schools in Yogyakarta still face a dilemma because of the strong desire to provide quality education with the lack of funds obtained from the government. To carry out quality guaranteed education, program and budget synchronization is needed through the budget planning at the beginning of each year. The programs or activities that are not carried out with planning can lead to not achieving the objectives. Therefore, a study is needed that examines the factors that contribute to budget planning in public elementary schools in Yogyakarta

\section{LITERATURE REVIEW}

\section{School Objective}

School objective affects planning budget because planning budget involves defining organization's goals and establishing strategies for achieving organization's goals (Robins \& Coulter, 2012). Organization goals need to be determined before planning a budget (Poston, 2011).The aim of the education program is to provide high-quality education that will prepare students to be active citizens, thinkers, critics, lifelong learners, and prepare students for their future (McMahon, 2013; Moran, 2018). Schools have an important role in society in preparing young people who are active and competent (Cranston, Mulford, Keating, \& Reid, 2010). In addition, the purpose of the school was initially focused on two types of objectives, namely improving performance and learning objectives aimed at developing competencies and mastery of tasks (Valle et al., 2009). In education, objective questions are multidimensional questions because education tends to function deeply in a number of domains, namely qualification, socialization and subjectivity.

\section{School Management}

School management is coordination from resources through the planning, organizing, directing, and controlling that require careful budget planning (Sisk, 1999). Management in education is effort to complete a education project, therefore this project requires budget planning maximally (Globerson \& Zwikael, 2002). School management can be successful with disciplined and careful budget planning (Joshi, 2001). Education 
management is a broad term covering everything related to management of education (Sun, 2014). Management aims to integrate academic standards with their implementation, which can efficiently increase the practical value of individual learning by combining group learning (Berggren \& Söderlund, 2008). School management covers a variety of roles and responsibilities in education programs to educate and train professionals who are involved in learning activities (Pant \& Baroudi, 2008). The school management system in the aspect of learning can provide instructors with efficient functions (Asiri, Mahmud, Abu Bakar, \& Mohd Ayub, 2012). School management is a system based on shared leadership, teamwork, and flexible teaching practices to handle student diversity (Passailaigue \& Estrada, 2018). Oplatka \& Arar (2017) stated that school management was implemented by school principals who aimed to provide a good working atmosphere for school staff.

\section{Work Involvement}

Work involvement is the extent to which a person views the importance of work in his life. (Griffin, Hogan, Lambert, Tucker-Gail, \& Baker, 2010). Work involvement is also considered as an employee's work behavior and has been defined as an employee's psychological identification or commitment to work (Mohsan, Nawaz, Khan, Shaukat, \& Aslam, 2011). Work involvement involves internalizing values about the importance of work in individual values (Saxena \& Saxena, 2015). Work involvement is a cognitive and emotional identification by individual employees with their work (Jayawardana, O’Donnell, \& Jayakody, 2013). Work involvement can be measured by several dimensions including actively participating in work, showing work as the main thing, and seeing his work as something important for self-esteem (Tiwari \& Singh, 2014).

\section{School Work Planning (SWP)}

The work planning is a decision made at this time on the desired future conditions. Netting \& Hash (2007) states that the work plan is the determination of organizational goals by developing strategies and developing new plans that can be used to achieve goals. The Budget planning was affected by systematic planning that includes income; expenditure related education program and goal wanted to achieve (Lipham, 1985). The strategic plan is a framework for solving problems that arise in education management (Miller \& Cardinal, 1994). School work planning is a disciplined effort to produce basic decisions and actions that shape and guide the organization (Poister \& Streib, 2005). School work planning is an important part of an organization because the rapid change in organizations requires creative and flexible strategies (Grant, 2003). A work plan is a part of planning for the future, by setting goals and finding ways to achieve goals (Dooris, Kelley, \& Trainer, 2004). To achieve the goal requires a maximum ability of the organization to achieve the goal (Tsiakkiros \& Pashiardis, 2002).

\section{Operational Work Planning (OWP)}

The operational plans or plans for program implementation are activities to improve program performance and determine a program's budget (Mabert, Soni, \& Venkataramanan, 2003). Operational plans are effective ways to improve a program (Fidalgo, Torrance, \& García, 2008). Operational planning is a concept or operational 
basis to honestly assess what an organization must do (Enderle \& Tavis, 1998). The operational plan is a strategy for looking ahead, so there is an effort to plan a prevention and modify it (Netting \& Hash, 2007). Operational plans are goals to achieve desires in terms of direction and intensity as evidenced by a change in life (Sniehotta, Schwarzer, Scholz, \& Schuz, 2005). The operational plan is an effort to develop a program, make an innovation and improve the practice of a program (Creasey \& Walther-Thomas, 1996).

\section{Budget Planning}

Anthony \& Govindarajan (2005) states that the budget is an important tool for effectively planning and controlling an organization. Budget usage usually covers one year and states income and expenditure for one year. Paulsen \& Smart (2001) states that the budget is a planned expenditure for a certain period of time. The budget planning is a management system that is used to implement policies correctly and effectively (Wen, Wang, \& Wang, 2005). The budget planning is the most effective way to help educational institutions in achieving institutional goals (Zierdt, 2009). The budget planning is influenced by the length of experience and management carried out by a manager (Sato, 2012). Based on the statement above, it can be concluded that budget planning is an important component in making and implementing an education program.

\section{METHOD}

\section{General Background}

The research used in this study is quantitative research, which is research based on the positivism philosophy with the aim to test the hypothesis that has been set. The data that has been collected is processed in numbers and analyzed quantitatively using Structural Equation Modeling (SEM). The results of the analysis are then interpreted and concluded. This research will prove eleven hypotheses. The first hypothesis; there is a significant effect of the school's objective variable on budget planning. The second hypothesis; there is a significant effect of school management variable on budget planning. The third hypothesis; there is a significant effect of the variable work involvement on budget planning. The fourth hypothesis; there is a significant effect of SWP variable on budget planning. The fifth hypothesis; there is a significant effect of OWP variable on budget planning. The sixth hypothesis; there is a significant effect of the school's objective variable on SWP. The seventh hypothesis; there is a significant effect of school management variable on SWP. The eighth hypothesis; there is a significant effect of work involvement variable on SWP. The ninth hypothesis; there is a significant effect of the school's objective variable on OWP. The tenth hypothesis; there is a significant effect of school management variable on OWP. The eleventh hypothesis; there is a significant effect of work involvement variable on OWP.

\section{Population and Sample of the Research}

The population in this study is all State Primary Schools in Yogyakarta Province. The number of State Primary Schools in Yogyakarta Province was as much as 1788. Sampling was taken by Cluster Random Sampling technique, namely by randomizing 
individuals in a group, namely elementary school. The cluster random sampling technique is used to determine the sample based on the school according to the accreditation rating, namely accreditation A, B, and C. Determination of the sample using Isaac \& Michael (1981) table showed 284 elementary schools with a 95\% confidence level. The number of samples in each elementary school proportionally was taken as much as $19.4 \%$, thereby obtained 112 of the 579 primary schools with accredited A, 162 primary schools of 836 primary schools with accredited B, and 10 elementary schools of 49 primary schools with accredited C.

\section{Research Variables}

This study uses six variables, namely; School destination variable with Indicators; (1) orientation, (2) desire, (3) can be measured, and (4) expected results. School management variable with indicators: (1) planning; (2) organizing; (3) implementation; (4) supervision; and (5) evaluation. Work involvement variable with indicators (1) participation; (2) representation and (3) contribution. School work planning variables (SWP) with indicators: (1) integrated; (2) multi years; (3) performance base; and (4) participatory. Operational work planning (OWP) with indicators: (1) budget; and (2) operational. Budget planning variables with indicators: (1) program, (2) financing, and (3) funding sources.

\section{Data Collection Technique}

Data were collection in this study using a closed questionnaire instrument compiled from the indicators observed. The questionnaire is a data collection technique that is done by giving a list of questions or written statements to obtain information from respondents. The questionnaire was compiled using a Rating scale consisting of 5 alternative answers, namely very good, good, good enough, not good, very bad. In this questionnaire, all alternative answers were listed so that the respondent could choose one of the appropriate answers.

\section{Validity and Reliability of Instruments}

\section{Validity of Instrument}

There are two types of validity that are used in this study, namely content validity and construct validity. The content validity is used to see how far the instrument in the form of a questionnaire that has been developed by the researcher is in accordance with the theory. The content validity in the study uses Aiken's validity formula (Aiken, 1980). In Aiken's validity, expert assessments were analyzed according to Aiken's formula with criteria; $0.00-0.40$ with Low or cannot be used; $0.40-0.80$ in the medium category or can be used, and $0.80-1.00$ in the high category or very good to use. The results of the Aiken validity analysis of all variables was obtained from 0.80 to 1.00 coefficients. This shows that all items developed were valid. The construct validity is used to see how far the indicators obtained from the theory are valid indicators in supporting the variables studied. The construct validity was analyzed using CFA (Confirmatory Factor Analysis) with the help of Lisrel 8.80. The instrument is said to be valid if it has a loading factor greater than 0.5 (Hair Jr, William, Babin, \& Anderson, 2014). The results of the CFA 
analysis which obtained the value of loading factor from the 6 variables studied had a value greater than $0.5(\lambda>0.5)$.

\section{Reliability of Instrument}

The reliability describes how far the instrument is consistent in obtaining data (Gay, 1981; Tuckman, 1972). The reliability calculations in this study use Cronbach Alpha. The instrument reliability coefficient for each variable of school objectives, school management, work involvement, school work planning, operational work planning, and budget planning are $0.86,0.941,0.87,0.88,0.85,0.92$. The construct reliability coefficient values are obtained as $.92,0.82,0.84,0.86,0.82,0.82$, respectively. Based on the coefficient value, it can be concluded that the instrument used to measure the six variables is reliable.

\section{Data Analysis Techniques}

The data analysis technique used in this study is SEM (Structural Equation Model). SEM is a statistical technique that tests complex relationships simultaneously. The complex relationships can be built between one or several dependent variables with one or several independent variables. The model that has been built will be evaluated by looking at the suitability of the model with the data obtained in the field. Like the measurement model, the criteria set to get a good model is to consult the size of the goodness of fit index (Standards for evaluating model fit can be used in accordance with expert advice, namely X2, RMSEA, GFI, AIC, NFI, IFI, and RFI).

\section{FINDINGS}

The SEM begins by specifying the research model or commonly called path diagram that will be estimated. The SEM analysis is used to test the hypothesis proposed in the study. The summary of SEM analysis with the help of Lisrel 8.80 can be seen in Table 1 and figure 1.

Table 1

The Summary of the Results of the Influence Test between Variables

\begin{tabular}{lccl}
\hline Variables & Coefficient & T-Value & Criteria \\
\hline School Objective $\rightarrow$ Budget Planning & 0,24 & 3,66 & Significant \\
School Management $\rightarrow$ Budget Planning & 0,16 & 2.27 & Significant \\
Work Involvement $\rightarrow$ Budget Planning & $-0,006$ & -0.08 & Not Significant \\
SWP $\rightarrow$ Budget Planning & 0,18 & 2,19 & Significant \\
OWP $\rightarrow$ Budget Planning & 0,37 & 4,27 & Significant \\
School Objective $\rightarrow$ SWP & 0,28 & 4.19 & Significant \\
School Management $\rightarrow$ SWP & 0,32 & 4,26 & Significant \\
Work Involvement $\rightarrow$ SWP & 0,22 & 2,94 & Significant \\
School Objective $\rightarrow$ OWP & 0,29 & 4.28 & Significant \\
School Management $\rightarrow$ OWP & 0,24 & 3,13 & Significant \\
Work Involvement $\rightarrow$ OWP & 0,24 & 3,13 & Significant \\
\hline
\end{tabular}




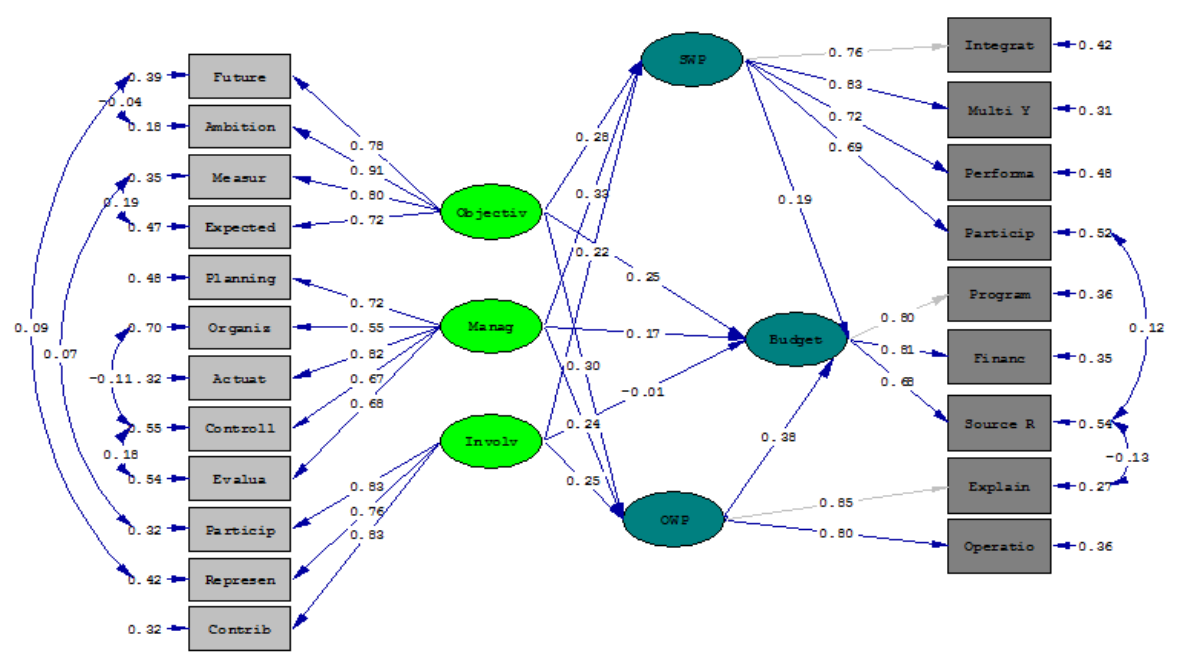

Figure 1

Chi-Square $=249.34, \mathrm{df}=166, \mathrm{P}-\mathrm{value}=0.00003, \mathrm{RMSEA}=0.042$

Structural Model of Standardized Solution

Based on the results of the analysis of structural equation modeling described in Table 1 and Figure 1, it is obtained the influence of exogenous variables on endogenous. The results of the analysis will prove the hypothesis proposed in this study. The first hypothesis is that there is a significant influence of school objective variable on budget planning variable. This statement is supported by the T-value value of 3.66 with the contribution value of the school's goal variable to the budget planning of $0.24(24 \%)$. The influence of the school objective variable on budget planning can be said to be good because the T-value is greater than $1.96(3.66>1.96)$. In other words, school objective variable significantly influence budget planning variable.

The second hypothesis is that there is a significant influence on school management variable on budget planning. Table 1 shows that there is a significant contribution of school management variable on budget planning of 0.16 . These results show that school management variable contributes $16 \%$ to budget planning. This result is supported by the results of the $t$ value of 2.27 , where the effect of a variable is said to be good if the value of the $\mathrm{T}$-value is greater than $1.96(2.27>1.96)$. The results of this analysis illustrate that the contribution of school objective variable to budget planning variable is significant at a $95 \%$ confidence level.

The third hypothesis is that there is a significant influence from the variable work involvement on budget planning. The results of structural equation modeling analysis show that the work involvement variable does not affect the budget planning variable because the effect is negative and not significant, which is -0.006 . In other words, the effect of work involvement variable is only $-0.6 \%$ on budget planning variable. In addition, the analysis results are also supported by the T-value value of $-0.08(-0.08$ 
<1.96). It means that the work involvement variable does not affect the budget planning variable.

The fourth hypothesis is that there is a significant influence of SWP variable on budget planning. The results of structural equation modeling of the exogenous SWP variable significantly influence the endogenous variables of budget planning. Based on Table 1 it is known that there is a significant influence of SWP variable on budget planning of 0.18 . In other words, SWP contributes $18 \%$ to budget planning. This is also supported by the T-value of 2.19 (2.19>1.96), so it can be concluded that the influence of SWP variable on budget planning variable is significant at $95 \%$ confidence level.

The fifth hypothesis is that there is a significant influence of OWP variable on budget planning. From Table 1 it is known that there is a significant influence of OWP on budget planning of 0.37 . In other words, the OWP variable contributes $37 \%$ to the budget planning variable. This is supported also by the result of the $t$ value of 4.27 where the effect is said to be good if the value of the T-value is greater than 1.96. The value of $t=4.27(4.27>1.96)$ means that the contribution of OWP variable on budget planning is significant at $95 \%$ confidence level.

The sixth hypothesis is that there is a significant effect of school objective variable on SWP variable. The results of SEM analysis show that school objective variable affects SWP variable. Based on Table 1 it is known that there is an effect of school objective on SWP of 0.28 . In other words, school objective contributes $28 \%$ to SWP variable. This result is supported by the T-value of 4.19. The effect is said to be good if the value of the T-value is greater than 1.96 (4.19>1.96), so it can be concluded that the effect of the school objective variable to SWP is significant at $95 \%$ confidence level.

The seventh hypothesis is that there is a significant influence of school management variable on SWP. The results of SEM analysis show that school management variable significantly influence SWP variables. Based on Table 1 it is known that there is a significant effect of school management variable on SWP of 0.32 so that it can be interpreted that the school management variable contributes $32 \%$ to the budget planning variable. This result is supported by the T-value of 4.26 or significant with a confidence level of $95 \%$.

The eighth hypothesis is that there is a significant influence on the variable of work involvement on SWP. This result is in accordance with the SEM analysis which shows that the variable work involvement has a contribution to the SWP variable. Based on Table 1, it is obtained that there is a significant influence of work involvement variable on SWP of 0.22 so that it can be interpreted that the work involvement variable contributes $22 \%$ to SWP variable. This result is supported by the T-value of 2.94 and is significant at $95 \%$ confidence level.

The ninth hypothesis is that there is a significant influence of school objective variable on OWP variable. The results of SEM analysis show that school goal variable significantly influences the OWP variable. From the summary of the analysis in Table 1, it can be seen clearly that there is an effect of the school objective variable on the OWP variable of 0.29 . This result shows that school objective contributes $29 \%$ to the OWP 
variable. The results of the analysis can also be seen from the T-value which is 4.28 and significant at the $95 \%$ confidence level $(4.28>1.96)$

The tenth hypothesis is that there is a significant effect of school management variable on the OWP variable. The results of SEM analysis prove that school management variable significantly influences the OWP variable. Based on Table 1, there is a significant influence of school management on OWP variable of 0.24. In other words, school management variable contributes $24 \%$ to the OWP variable. This result is supported by the T-value of 3.13, where the effect is said to be good if the value of the $\mathrm{T}$-value is greater than $1.96(3.13>1.96)$. The influence of school management variable on OWP variable is significant at $95 \%$ confidence level.

The eleventh hypothesis is that there is a significant effect of the variable work involvement on the OWP variable. The results of SEM analysis prove that the work involvement variable influences the OWP variable. Based on Table 1, it can be concluded that there is an effect of the work involvement variable on the OWP variable of 0.24 or the contribution of the work involvement variable of $24 \%$ to the OWP variable. This result can be seen from the T-value of 3.13 or significant at $95 \%$ confidence level (3.13>1.96). In other words, the contribution of work involvement to the OWP variable is significant at $95 \%$ confidence level.

Based on SEM testing with the help of Lisrel 8.80 software, it begins by specifying the research model that will be estimated. From the results of the analysis, the summary of the suitability of the whole model is obtained using the Goodness Of Fit (GOF) analysis. Based on the findings of the empirical model using 7 criteria for measuring Goodness of Fit $(\mathrm{GOF})$ obtained values of $\mathrm{X} 2=249.34<332, \mathrm{RMSEA}=0.042, \mathrm{GFI}=0.923, \mathrm{AIC}=$ $0.968, \mathrm{NFI}=0.988, \mathrm{IFI}=0.988$, and RFI $=0.959$. Based on this number it can be concluded that the model is fit. In other words, there are no differences in theoretical models with empirical models.

\section{DISCUSSION}

\section{School Objective}

The purpose of the school is a condition that is expected to occur in the future. School objective proved to have significant contributions to budget planning with 0.24 or Tvalue $=2.96$. Mulyono (2008) stated that the success of a school in providing quality education is inseparable from good school budget planning and the allocation of targeted and effective education funds. Purwanto (1995) stated that the requirements for preparing a school budget plan must be based on clear objectives. If the school objective is well formulated and easily understood, it will have a direct impact on good budget planning as well.

School objective also contributes to SWP variable and OWP variable. The effect of school objective is significant on SWP variable of $0.28(28 \%)$. The contribution of school objective is significant to OWP variable with the value of 0.29 . Muhaimin, Sutiah, \& Prabowo (2011) stated that school objectives are used as a guide in preparing activities to be carried out within a certain time to realize the planned program. Akdon 
(2006) stated that the objectives should not be stated in quantitative form, but must be able to show the conditions that the school wants to achieve in the future. The aim will be to formulate program policies and activities in order to realize the mission. This gives the meaning that a good school's objective will direct the formulation of goals, policies, programs, and activities in order to realize the mission embodied in SWP and OWP.

\section{School Management}

The school management authorizes schools to make plans according to school needs. The school management variable proved to contribute significantly to the budget planning of 0.16 , which means that the school management variable contributes to budget planning by $16 \%$. This finding gives the meaning that schools in planning school needs have been adapted to school abilities. The principal has supervised and provided answers if there is input from subordinates as a form of evaluation. The school management contributes to the problems related to education, providing solutions that include financial mechanisms from the activities of educational institutions (Kamasheva et al., 2016).

The school management variable also influences the SWP and OWP variable. The effect of school management variable on SWP is 0.32 (school management's contribution to SWP is $32 \%$ ). The effect of school management variable on OWP is significant to management variable with the value of 0.24 (school management's contribution to OWP is $24 \%$ ). The school management is also needed to provide benefits to work with the efficiency of time and effort to be taken (Kirillov, Tanatova, Vinichenko, \& Makushkin, 2015). The management can help to achieve quality, efficient and effective goals (Passailaigue \& Estrada, 2018).

\section{Work Involvement}

The person's work involvement is influenced by psychologically strong motivation in problem-solving and decision making. The variable of work involvement is not significant to budget planning because the effect is only -0.006 . These results indicate that the contribution of the work involvement variable is only $-0.6 \%$ of budget planning. This finding gives the meaning that the preparation of school programs has not fully involved school stakeholders, including participation in meeting invitations. The existence of school committees has not been able to actively increase community participation. Wulaningrum (2011) found that there was employee work involvement in the preparation of school budgets, but the work involvement of employees in the school budgeting process was still very small. However, the variable work involvement contributes significantly to the SWP and OWP variable. The contribution of the variable work involvement is significant to the SWP variable with the value of 0.22 (contribution of $22 \%$ ). The contribution of the variable work involvement is significant to the OWP variable of 0.24 (contribution of 24\%). Biswas (2009) explains that with increasing work involvement, it will increase the effectiveness and productivity of the organization in a program designed. The planning of the use of school operational assistance funds begins with the preparation of the OWP. 


\section{School Work Planning (SWP)}

The SWP is a comprehensive plan to optimize the use of school resources. The SWP is an attempt to formulate what an organization really wants to achieve and how to achieve it. The SWP variable is proven to significantly influence the budget planning of 0.18 (contribution of 18\%). This finding shows that schools can accommodate school programs into SWP. In other words, a well-prepared SWP will have a positive impact on budget planning. Sahertian (1994) states that SWP is an activity that will be carried out by schools and contains school activities that are arranged systematically and directed for a predetermined period of time.

\section{Operational Work Planning (OWP)}

The OPW is an annual work plan derived from SPW. The OPW variable proved to be significant in influencing budget planning by 0.37 (contribution OPW variable to budget planning variable is $37 \%$ ). These results indicate that the fifth hypothesis is proven. Rohiat (2008) in his research stated that the budget preparation process in OPW was carried out in a clear, measurable and detailed way to make it easier to determine the number of funds needed for the implementation of the program. Hapsari \& Sukirno (2015) stated that OWP contained information on the amount of costs that would be incurred by schools and resources to fund education costs. The schools in drafting the OWP have described plans for funding activities for a one-year budget. Schools also describe in detail about what actions must be taken to achieve school goals.

\section{CONCLUSION}

Based on the findings of the empirical model, using the 7 criteria for measuring Goodness Of Fit (GOF), namely X2 $=249.34<332$, RMSEA $=0.042$, GFI $=0.923$, AIC $=0.968, \mathrm{NFI}=0.988, \mathrm{IFI}=0.988$, and RFI $=0.959$ can concluded that the model is in accordance with the data obtained in the field. This shows that the empirical model meets all the specified criteria, so it can be concluded that the model is fit. In other words, there are no differences between theoretical models with empirical models. From the proposed Hypothesis, there are four variables that influence budget planning variable, namely school objective, school management, SWP, and OWP, while the work involvement variable does not affect the budget planning variable. The school objective variable affects the SWP and OWP variable. The school management variable affects the SWP and OWP variables. The variable of work involvement also affects the SWP and OWP variables. All indicators that form budget planning variable, school objective variable, school management variable, SWP variable and OWP variable are valid.

\section{SUGGESTION}

School budget planning is very important to implement school objective in improving school quality. Therefore, government must pay attention to school in helping school budget planning so that schools' programs can be run well. School objective need to be socialized to community so that the community can give advice to school on what should school do in improving school quality. School management need to be improved well because school management can determine what programs should be implemented 
with school budget. School budget planning must be arranged by someone who has experience and strong commitment so that school budget planning can be done well without any mistake.

\section{REFERENCES}

Aiken, L. R. (1980). Content Validity and Reliability of Single Items or Questionnaires. Educational and Psychological Measurement, 40(V), 955-959.

Akdon. (2006). Strategic management for educational management. Bandung: Alfabeta.

Asiri, M. J., Mahmud, R. B., Abu Bakar, K., \& Mohd Ayub, A. F. Bin. (2012). Factors Influencing the Use of Learning Management System in Saudi Arabian Higher Education: A Theoretical Framework. Higher Education Studies, 2(2), 125-137. https://doi.org/10.5539/hes.v2n2p125

Berggren, C., \& Söderlund, J. (2008). Rethinking project management education: Social twists and knowledge co-production. International Journal of Project Management, 26(3), 286-296. https://doi.org/10.1016/j.ijproman.2008.01.004

Biswas, S. (2009). Job satisfaction and job involvement as mediators of the relationship between psychological climate and turnover intention. South Asian Journal of Management, 16(1), 27-43.

Cranston, N., Mulford, B., Keating, J., \& Reid, A. (2010). Primary school principals and the purposes of education in Australia: Results of a national survey. Journal of Educational Administration, 48(4), 517-539. https://doi.org/10.1108/09578231011054743

Creasey, S. M., \& Walther-Thomas, C. (1996). Using Planning Teams To Implement Inclusive Education Effectively. Preventing School Failure, 41(1), 39-43. https://doi.org/10.1080/1045988X.1996.9944683

Dooris, M. J., Kelley, J. M., \& Trainer, J. F. (2004). Strategic planning in higher education. New Directions for Institutional Research, (123), 5-11. https://doi.org/DOI: 10.1002/ir.115

Enderle, G., \& Tavis, L. A. (1998). A balanced concept of the firm and the measurement of its long-term planning and performance. Journal of Business Ethics, 17(11), 11291144. https://doi.org/10.1023/A:1005746212024

Fidalgo, R., Torrance, M., \& García, J. N. (2008). The long-term effects of strategyfocussed writing instruction for grade six students. Contemporary Educational Psychology, 33(4), 672-693. https://doi.org/10.1016/j.cedpsych.2007.09.001

Gay, R. (1981). Educational research. London: Charles E. Merril Publishing Co.

Globerson, S \& Zwikael, O. (20120. The Impact of the Project Manager on Project Management Planning Processes. Project management journal, 33(2), 58-64. https://doi.org/10.1177/875697280203300308 
Grant, R. M. (2003). Strategic planning in a turbulent environment: Evidence from the oil majors. Strategic Management Journal, 24(6), 491-517. https://doi.org/10.1002/smj.314

Griffin, M. L., Hogan, N. L., Lambert, E. G., Tucker-Gail, K. A., \& Baker, D. N. (2010). Job involvement, job stress, job satisfaction, and organizational commitment and the burnout of correctional staff. Criminal Justice and Behavior, 37(2), 239-255. https://doi.org/10.1177/0093854809351682

Hair Jr, J. F., William, C., Babin, B. J., \& Anderson, R. E. (2014). Multivariate Data Analysis Joseph F . Hair Jr. William C. Black Seventh Edition.

Hapsari, A., \& Sukirno. (2015). Analisis biaya satuan pendidikan di SMK negeri I jogonalan tahuan ajaran 2014/2015. Jurnal Pendidikan Akuntansi Indonesia, 27-34.

Isaac, S., \& Michael, W. (1981). Handbook in research and evaluation. California: Edits Publisher.

Jayawardana, A. K. L., O’Donnell, M., \& Jayakody, J. A. S. K. (2013). Job involvement and performance among middle managers in Sri Lanka. International Journal of Human Resource Management, 24(21), 4008-4025. https://doi.org/10.1080/09585192.2013.781526

Joshi. (2001). The international diffusion of new management accounting practices: the case of India. Journal of International Accounting, Auditing \& Taxation ,10 (2001), 85109. https://doi.org/10.1016/S1061-9518(01)00037-4

Kamasheva, Y. L., Goloshumova, G. S., Goloshumov, A. Y., Kashina, S. G., Pugacheva, N. B., Bolshakova, Z. M., ... Timirov, F. F. (2016). Features of vocational education management in the region. International Review of Management and Marketing, 6(1), 155-159.

Kirillov, A. V., Tanatova, D. K., Vinichenko, M. V., \& Makushkin, S. A. (2015). Theory and practice of time-management in education. Asian Social Science, 11(19), 193-204. https://doi.org/10.5539/ass.v11n19p193

Lipham, J. M. (1985). The principalship. New York: Longmen

Mabert, V. a., Soni, A., \& Venkataramanan, M. a. (2003). Enterprise resource planning: Managing the implementation process. European Journal of Operational Research, 146(2), 302-314. https://doi.org/10.1016/S0377-2217(02)00551-9

McMahon, B. J. (2013). Conflicting Conceptions of the Purposes of Schooling in a Democracy. Journal of Thought, 48, 17-32.

Miller, C. C., \& Cardinal, L. B. . (1994). Strategic Planning and Firm Performance : A Synthesis of More than Two Decades. Academy of Management, 37(6), 1649-1665.

Mohsan, F., Nawaz, M. M., Khan, M. S., Shaukat, Z., \& Aslam, N. (2011). Are employee motivation, commitment and job involvement inter-related: Evidence from banking sector of Pakistan. International Journal of Business and Social Science, 2(17), 
226-233.

Moran, S. (2018). Purpose-in-action education: Introduction and implications. Journal of Moral Education, 47(2), 145-158. https://doi.org/10.1080/03057240.2018.1444001

Muhaimin, Sutiah, \& Prabowo, L. (2011). Manajemen pendidikan: Aplikasi dalam penyusunan rencana pengembangan Sekolah/Madrasah. Jakarta: Kencana Prenada Media Group.

Mulyono. (2008). Manajemen administrasi dan organisasi pendidikan. Yogyakarta: ArRuzz Media.

Netting, F. E., \& Hash, K. (2007). Long-term planning and decision-making among midlife and older gay men and lesbians. Journal of Social Work in End-of-Life \& Palliative Care, 3(2), 59-77. https://doi.org/10.1300/J457v03n02

Oplatka, I., \& Arar, K. (2017). The research on educational leadership and management in the Arab world since the 1990s: A systematic review. Review of Education, 5(3), 267-307. https://doi.org/10.1002/rev3.3095

Pant, I., \& Baroudi, B. (2008). Project management education: The human skills imperative. International Journal of Project Management, 26(2), 124-128. https://doi.org/10.1016/j.ijproman.2007.05.010

Passailaigue, R. M., \& Estrada, V. (2018). Educational Management with Technology Support. International Journal of Applied Engineering Research, 13(12), 1064710650.

Poister, T., \& Streib, G. (2005). Elements of strategic planning and management in municipal government: Status after two decades. Public Administration Review, 65(1), $45-56$.

Poston, W. (2011). School budgeting for hard times. Thousand Oaks: Corwin A Sage Company.

Purwanto, N. (1995). Administrasi dan supervisi pendidikan. Bandung: PT. Remaja Rosda Karya.

Robins, S. P., \& Coulter, M. (2012). Mangement. In Management (Eleven, Vol. 40, p. 9823). Upper Saddle River: Pearson Prentice Hall. https://doi.org/10.1002/15213773(20010316)40:6<9823::AID-ANIE9823>3.3.CO;2-C

Rohiat. (2008). Manajemen sekolah: Teori dasar dan praktik. Bandung: PT. Refika Aditama.

Sahertian, P. (1994). Profil Pendidik Profesional. Yogyakarta: Andi Offset.

Sato, Y. (2012). Optimal budget planning for investment in safety measures of a chemical company. International Journal of Production Economics, 140(2), 579-585. https://doi.org/10.1016/j.ijpe.2012.05.030

Saxena, S., \& Saxena, R. (2015). Impact of Job Involvement and Organizational 
Commitment on Organizational Citizenship Behavior. International Journal of Management and, 5(1), 19-30.

Sisk, H. L. (1999). Principles of management: A system approach to the management process, England: South-Western Publishing Company

Sniehotta, F. F., Schwarzer, R., Scholz, U., \& Schuz, B. (2005). Action planning and coping planning for long-term lifestle change, Theory assessment. European Journal of Social Psychology, 35(December 2004), 565-576. https://doi.org/10.1002/ejsp.258

Sun, M. (2014). 30 years of Chinese educational management: achievements, characteristics and problems. International Journal of Educational Management, 28(3), 340-348. https://doi.org/10.1108/EL-01-2017-0019

Tiwari, V., \& Singh, S. K. (2014). Moderation effect of Job Involvement on the relationship between Organizational Commitment and Job Satisfaction. SAGE Open, 4(2), 1-7. https://doi.org/10.1177/2158244014533554

Tsiakkiros, A., \& Pashiardis, P. (2002). Strategic planning and education: The case of Cyprus. International Journal of Educational Management, 16(1), 6-17. https://doi.org/10.1108/09513540210415505

Tuckman, W. (1972). Conducting educational research. New York: Harcourt Brace Javannovich inc.

Valle, A., Núñez, J. C., Cabanach, R. G., González-Pienda, J. A., Rodríguez, S., Rosário, P., ... Cerezo, R. (2009). Academic Goals and Learning Quality in Higher Education Students. The Spanish Journal of Psychology, 12(1), 96-105. https://doi.org/10.1017/S1138741600001517

Wen, W., Wang, W. K., \& Wang, C. H. (2005). A knowledge-based intelligent decision support system for national defense budget planning. Expert Systems with Applications, 28(1), 55-66. https://doi.org/10.1016/j.eswa.2004.08.010

Wulaningrum, R. (2011). Partisipasi pegawai dalam penyusunan anggaran sekolah studi kasus pada SMP negeri 10 Samarinda. Jurnal Eksis, 7, 1873-1883.

Zierdt, G. L. (2009). Responsibility-centred budgeting: An emerging trend in higher education budget reform. Journal of Higher Education Policy and Management, 31(4), 345-353. https://doi.org/10.1080/13600800903191971 